\title{
What drives sub-national bioenergy development? Exploring cross-level implications of environmental policy integration in EU and Swedish bioenergy policy
}

Charlotta Söderberg, Luleå University of Technology

\begin{abstract}
What are the sub-national implications, in policy and practice, of environmental policy integration (EPI) in EU and Swedish bioenergy policy? Focusing on the exceptional bioenergy expansion within the Biofuel Region in north Sweden, this paper discusses cross-level implications of supranational and national policy decisions on bioenergy; whether environmental perspectives are observable also in sub-national bioenergy discussions; and explores the drivers of sub-national bioenergy development in a multi-level governance setting. The study finds that higher-level EPI plays an important role for sub-national bioenergy development. The degree of sub-national EPI in bioenergy and the type of renewables invested in is to a large extent set by top-down influence from the EU and national level through agenda setting, policy goals and economic mechanisms. Local policy entrepreneurs play an important role for finding 'win-win'-solutions that can help initiating local energy projects and ensure sub-national EPI, but environmentaleconomic - rather than merely economic - motives for getting involved are important to ensure long-term local commitment to renewable energy projects.
\end{abstract}

\section{JEL classification}

\section{Keywords}

Bioenergy; sub-national; cross-level EPI; regulation; Sweden; multi-level governance. 


\section{Introduction}

This paper focuses on cross-level implications of supranational and national bioenergy policy for sub-national bioenergy development. Bioenergy is energy (electricity and transport fuels) derived from biomass (i.e. by-products from forestry and agriculture, municipal and industrial waste streams and dedicated energy crop cultivation, EC, 2005; EEA, 2006). Through studying the effect of EU and Swedish bioenergy policy on the developments in the Biofuel Region area in Sweden, which is the site for a unique expansion in the biofuel industry over the last decade, this paper provides insight into what works, when and how for stimulating sub-national renewable energy development.

Overarching policies are formed and policy instruments are instated on the supranational and national levels. One overarching policy objective that has influenced EU and Swedish bioenergy policy for the last decades is environmental policy integration (EPI), which endeavours to incorporate environmental policy objectives into all sector policies with a view to promote sustainable development (WCED 1987). EPI is a key objective within EU- and Member State policy (under Article 6.1. of the Lisbon Treaty). There is a rich literature available on EPI, to a large extent focusing on the European and national levels (e.g. Lenschow, 2002; Nilsson and Eckerberg, 2007; Jordan and Lenschow, 2008; Lafferty, 2004). However, sub-national actors are the ones who, in the end, are left with the delicate task of interpreting and realising higher-level policies. In other words, the sub-national level is the level on which policy comes to life; where policy moves from rhetoric to practice. Thus, the sub-national level can be said to hold the key to the realisation of sustainable development ambitions, such as renewable energy expansion. However, as Urwin and Jordan (2008, p. 182, based on Radaelli, 2003) argue: "the way in which the intentions of policy are expressed at the higher level, can be very different to the way in which it is actually conducted (and thus interacts with cognate policies) at lower levels".

Thus, in order to fully understand the process, and results, of environmental policy integration it is highly relevant to start scrutinising cross-level implications of EPI; not only on the supranational and national levels, but also on the sub-national level. Therefore, the overarching aim of this article is to explore the following question: what are the sub-national implications, in policy and practice, of EPI in EU and Swedish bioenergy policy? How do efforts to promote EPI at EU and national levels influence the development within bioenergy investments at subnational level (or is it rather the sub-national level that affects EPI in EU and national policy)? Apart from shedding light on cross-level EPI, the particular focus on the field of sub-national bioenergy expansion provides insights into the crosslevel implications of EU and Swedish bioenergy policy, and into what drives subnational bioenergy development.

The theoretical and empirical focus of the study is further developed below in this section. The second section provides a theoretical background, where key concepts are discussed and defined and an analytical framework and methodology for the study of sub-national EPI is outlined. The sub-national development and framing of bioenergy is explored in the third section. Then, the cross-level influence of European and Swedish bioenergy policy on the development within the Biofuel Region is discussed in the fourth section. Finally, conclusions and policy implications are discussed.

\section{A cross-level analysis focusing on the biofuel region in Sweden}

With regard to previous studies on cross-level implications of environmental policy, there are general studies on regional governance for sustainable development (e.g. Eckerberg and Forsberg, 1998; Lafferty and Narodoslawsky, 2003), and on governance for sustainable development at the inter-subnational level (Happaerts 
et al., 2010). As regards EPI on the sub-national level, Goria et al (2010) maps out current research with an overarching perspective on EPI on different levels including the sub-national level. However, the focus in this paper - i.e. the subnational policy-making arena and the interplay between the three different policy levels (EU, national, sub-national) in specific policy areas - are still virtually black areas within our understanding of EPI.

According to Jordan and Lenschow $(2008,2010)$, three main analytical dimensions of EPI exist: 1) an institutional perspective, focusing on EPI as a policy coordination problem; 2) a political perspective, focusing on EPI as a problem of political conflict and lobbying; 3 ) a cognitive perspective, focusing on different actor interests, how they are embedded within ideational frames, and how cognitive learning occurs. In this paper, a cognitive, 'reframing' approach to EPI is taken. Accordingly, EPI is viewed as a process where policymakers and actors in non-environmental policy sectors gain environmental knowledge, reframe their view of a certain policy area/issue and change their actions accordingly.

Sweden has been awarded high EPI 'scores' with this approach to EPI (Nilsson and Persson, 2003; Swartling et al 2007; Nilsson and Eckerberg, 2007). Sweden is also given high EPI-scores in other types of EPI-analyses focusing on the available environmental management systems in a country (e.g. Jacob and Volkery, 2004). The overall high EPI scores, together with the country's reputation of being a forerunner in environmental policy (Lundqvist, 2001, 2004; Kronsell, 2006) and the fact that Sweden can be considered a "critical most-likely case for EPI" (Nilsson, 2005a, p. 16) makes Sweden a relevant case for exploring cross-level implications of EPI.

Bioenergy policy is a policy area where EPI has been observed on both the EUand Swedish policy levels over the last decades. According to previous studies, the framing of bioenergy in EU- and Swedish policy today includes an environmental perspective (Söderberg, 2008; 2011a; 2011b; Söderberg and Eckerberg, 2013). This makes the sub-national Swedish level a relevant case for exploring cross-level EPI in bioenergy policy. Since the EU, its member states and the sub-national entities constitute a multi-level-governance system, the sub-national interpretation of-, influence by-, and contribution to national- and EU-policies is essential to study.

Two subsets of questions guide the analysis. First, given that we know how bioenergy policy is framed on EU and Swedish levels: how do bioenergy actors in a sub-national Swedish setting frame bioenergy? Through analysing the sub-national framing of bioenergy over time, the driving forces for sub-national bioenergy development can be detected. Are there similarities/differences between the bioenergy frames on different levels and are environmental issues integrated also on the sub-national level? Second, how can sub-national bioenergy development be explained in a multi-level setting? Through comparing the framing of bioenergy on different levels, the direction of policy impulses can be indicated - what policy level reframes policy first - EU, Swedish, or sub-national? Furthermore, interviews with key Biofuel Region actors provide insight into what role EU and Swedish bioenergy policy, respectively, play for sub-national bioenergy development.

The case of sub-national bioenergy expansion in focus of this study is the Biofuel Region in Sweden, which is a strategic network uniting public and private actors such as municipalities, national agencies, researchers and business interests in the four northernmost Swedish counties. The Biofuel Region was initiated in 2003 "with a view to creating and managing the development of an entirely new industry centred on renewable fuels from cellulose-based raw materials obtained from forest, field and recycling sources" (Christensen, 2005, p. 18) and was then mainly situated in two counties in the north of Sweden, but has expanded geographically as the biofuel interest has grown over the past seven years. In terms of visible results, there were nine gas stations within the Biofuel Region offering E85 (bioethanol) in 2003, and the demand on 'green cars' was small (BFR, 2006). In 
2009, there were 75 gas stations offering E85 (bioethanol) and two gas stations providing biogas. Four percent of all cars within the Biofuel Region in 2009 and 33 percent of the new cars sold within the Biofuel Region in 2009 were classified as 'green cars' (BFR, 2009). In 2010, four production sites for biogas, one for DME (dimethyl ether) and pine diesel and one for bioethanol were running in the region. This is a unique expansion in Sweden.

The Biofuel Region originally focused on developing production of cellulose-based biofuels (mainly bioethanol and biodiesel), but has since then broadened its scope to include other types of biofuels, such as biogas. Therefore, the development within the Biofuel Region, besides providing insight into sub-national bioenergy development, may also have something to tell us about the driving forces behind choosing to promote certain types of energy sources on the sub-national level. The Biofuel Region is a pioneering case in terms of regional biofuel development in Sweden; it is a famous project, which has been running for a decade. These characteristics make the region highly relevant to study in the context of subnational bioenergy development and cross-level EPI. There is no other comparable case on the sub-national level in Sweden. Focus in the study lies on exploring the driving forces behind this development, whether environmental policy integration on the EU and Swedish levels has any impact on the sub-national level development, and whether the Biofuel Region has any impact on the development at the EU and Swedish levels.

\section{Analytical framework and methodology}

Here, the theoretical background is further developed and key concepts such as EPI, reframing, policy learning and multi-level governance are discussed and defined. The methodology of the study is also addressed here. The first part of this section outlines the analytical framework and methodology for answering the first central question of the study, while the second part outlines the analytical framework and methodology for answering the second central question of the study.

\section{A policy learning approach to EPI}

The first central question explored here is: how do bioenergy actors in a subnational setting frame bioenergy? Given that we know that EPI has occurred on the EU- and Swedish level in bioenergy policy, it is relevant to explore the driving forces for sub-national bioenergy development. Since the Biofuel Region area is the site for a unique expansion in the biofuel industry over the last decade, this analysis will provide insight into what works, when and how for stimulating subnational renewable energy development. Furthermore, through exploring the framing of bioenergy it is also possible to discern whether the sub-national framing of bioenergy qualifies as EPI.

To discern integration of environmental aspects in this study, EPI is viewed as a policy learning process (Söderberg, 2011b). Learning can be studied on the individual or collective level (Kemp and Weehuizen, 2005). Collective learning, in turn, can be studied as organisational learning (e.g. Argyris and Schön, 1978) or, in broader contexts, as social learning (Reed et al, 2010, Nilsson and Swartling, 2009). Here, learning is studied on the collective level, with focus on a specific type of collective learning: policy learning (Kemp and Weehuizen, 2005), which "implies a change in thought about policy, which subsequently contributes to a change in the policy process" (Swartling et al 2007, p. 50). Sabatier (1993, p. 19) defines policy learning as "a relatively enduring alteration of thought or behavioural intentions that are concerned with the attainment (or revision) of the precepts of a policy belief system". Thus, EPI is detected through looking for policy learning, inducing policy change. 
The main tool for tracing policy learning here is studying how policy is framed over time. Frames can be said to shape actors' conception of reality, but when actors are provided with new knowledge (through e.g. research reports, media attention or lobbying) this can incite a learning process, which may lead to reframing. When such a reframing towards environmental sustainability occurs, environmental policy integration can be detected (Rein and Schön, 1993; 1994; Nilsson, 2005; Hall, 1993). However, the reframing must be visible in both policy rhetoric and in motives for policy measures to qualify as EPI, which here is defined as in Söderberg (2008), where environmental rhetoric in combination with environmental considerations underpinning policy practice (i.e., policy strategies are adopted on environmental grounds) constitute indicators for EPI (see also Nilsson and Persson, 2003).

There are also other types of learning, which may entail environmental reframing without qualifying as EPI; if environmental concerns are visible only in policy rhetoric but not followed-up in political measures it qualifies as rhetorical environmental learning. If environmental concerns are visible only in policy instruments (for example, as a response to regulatory requirements) it qualifies as instrumental environmental learning (Nilsson, 2005). EPI, on the other hand, thus requires a combination of both types of environmental learning, which signals a deeper entrenchment of environmental issues in both policy rhetoric and instruments. The view on EPI adopted here - environmental policy integration as a learning process traced through studying policy frames- has been developed and tested in previous research. For more elaborate discussions on the framing approach to EPI, please see Lenschow and Zito (1998), Nilsson and Eckerberg (2007) and Söderberg (2011b).

But is it enough that environmental aspects are included in policy rhetoric and practice in order to qualify as EPI? That depends on how rigidly we interpret the EPI concept. There are on-going discussions within EPI research regarding what priority has to be awarded to environmental issues in order to qualify as EPI (see e.g. Lafferty and Hovden, 2003; Baker, 2007). In an overview of different interpretations of the 'E' (environmental) and the ' $I$ ' (integration) in EPI, Söderberg (2011b, p. 26) concludes that 'it is possible to interpret the ' $E$ ' either from an anthropocentric worldview, aiming for ecological modernisation/the three-tiered sustainable development concept; or from an ecocentric worldview, aiming for ecologically sustainable development through significant value and lifestyle changes. Similarly, the meaning of 'l' can be interpreted either as "adding environment and stir", i.e. paying consideration to the environment in sector policymaking; or as giving principled and consequential priority to environmental issues". Thus, based on whether the environment is prioritised in Biofuel Region policy documents ('strong EPI'), or if it is mainly considered together with other types of issues ('weak EPI'), the strength of the integration of environmental issues within Biofuel Region can be evaluated.

The analysed materials consist of five Biofuel Region reports of activities (for the years 2003-2010, available on the Biofuel Region webpage), printouts from ten semi-structured telephone interviews conducted in 2010 with all Biofuel Region board members (representing small and large municipalities; industries; research; and central administrations) $)^{1}$, and a study from 2005 on the development of the

\footnotetext{
1 The interview questions were sent out to the interviewees before the interview. The interview questions focused on four main themes. 1) Purpose: explain the purpose of BFR; why did your organisation choose to join the BFR; what explains the initial focus on ethanol; what explains the broadened area of interest and geographical areas? 2) Underlying problems: what problems does BFR aim to help solving; what problems does BFR encounter; on what grounds do municipalities choose to support the BFR; on what grounds have municipalities left the BFR? 3) Policy networks: what actors does your organisation cooperate with regarding bioenergy issues; how do national/EU policy/regulations affect your bioenergy work; how does the BFR affect national/EU politics? 4) Political
} 
Biofuel Region (Christensen, 2005). The bioenergy policy frame(s) present within the Biofuel Region is detected through idea analysis (Bergström and Boreus 2005), analyzing the selected material on the basis of four thematic questions: Policy goals; what are the overarching policy goals for the Biofuel Region? Underlying problems; what are the main problems that the Biofuel Region is to address, and what problems does the Biofuel Region face? Policy preferences (instruments and strategies); what policy instruments is the Biofuel Region promoting, and how are the Biofuel Region's goals to be achieved? Promoted values and role of bioenergy; what values are promoted, and what is the role of bioenergy? The article examines how these four themes have been articulated in the Biofuel Region between the years 2003-2010 to detect the policy frames guiding the Biofuel Region. What are the driving forces for sub-national bioenergy development; has it changed over time; and (if so) what may explain these shifts?

\section{Sub-national bioenergy development in a multi-level governance setting}

The second central question analysed here is: how can sub-national bioenergy development be explained in a multi-level setting? What role do EU and Swedish bioenergy policies, respectively, play for bioenergy development according to subnational bioenergy actors? This question has to do with the multi-level character of the EU system, and the fact that if sustainable development is to be achieved in practice; EPI must occur on all levels (e.g. Stagle, 2007). The increasing interdependence between different policy levels has been analysed within multilevel governance (MLG) theory (Hooghe and Marks, 2004). Bache and Flinders (2004) derive four common understandings of MLG: increased participation in policy making by non-state actors; that distinct decision making levels are becoming more difficult to discern; a new role of the state in this new environment; and a new decision making context which makes it necessary to rethink democratic accountability.

In this context, according to Oberthür and Gehring (2006), the effectiveness of environmental governance instruments, such as European or national environmental instruments, is affected by interinstitutional influence from other regimes/policy instruments. Since realisation of bioenergy policy goals within the EU thus depends on a multi-level governance (MLG) system, this article explores the impact from European and Swedish bioenergy policy on the sub-national development within the Biofuel Region in order to analyse whether efforts to promote EPI at supra-national and national levels influence the development within a policy area at sub-national level (and vice versa). To this aim, the Biofuel Region actors were encouraged in the interviews (for details, please see endnote 1) to elaborate on to what extent they experience that EU bioenergy policy and Swedish bioenergy influence the development of bioenergy in the Biofuel Region area (in order to explore the top-down influence between bioenergy policy levels). The Biofuel Region actors were also asked whether they deem that they have any influence on Swedish and European bioenergy policy development (in order to explore the bottom-up influence between bioenergy policy levels).

How can the exceptional biofuel expansion within the Biofuel Region be explained? In order to start analysing this question we need to dwell a little on what institutional factors are put forward as conducive to EPI and local sustainable development in previous research. Policy learning is put forward as an important feature of sustainable development by many authors (e.g. Folke et al., 2002; Gunderson and Holling, 2002; Nilsson and Eckerberg, 2007). Stagle (2007) concludes after a

preferences: how does the BFR work to achieve their goals; what policy instruments are advocated; does different arguments work differently on different actors? 
thorough review of different learning theories that "the special challenge for learning for sustainable development is...to help establish procedures, management practices and institutions for public decision-making that support learning processes on multiple scales"(p. 59). Therefore, the interviewees were also asked to map out the cross-level contacts, which the Biofuel Region is involved in.

Nilsson and Eckerberg (2007) identify participant's trust in that they benefit from cooperation; development of trust and joint-problem perceptions; alignment of reframing with short-term sector interests; and strong political leadership as important factors for cognitive EPI. Furthermore, they maintain the importance of 'issue-champions' and issue networks within sectors to make sure that sustainability issues are receiving attention throughout the policy cycle. Previous EPI-studies have also pointed to the relevance of external factors (such as media attention), policy windows and 'policy entrepreneurs' (Kingdon, 1995) for EPI development. The role of win-win situations and political and individual leadership for local sustainable development is also supported by Eckerberg and Forsberg's (1998) study of Local Agenda 21 processes in Sweden, which shows that the combination of policy entrepreneurs and the possibility to solve local structural problems often spur successful local sustainable development strategies. To address this issue, interviewees were asked about the driving forces for joining the Biofuel Region.

Given that also structural factors are important for understanding EPI, as 'bridges' between environmental issues and other, economic, policy areas - that is, environment-economy win-win situations - are conducive for EPI (Nilsson and Eckerberg, 2007; Söderberg, 2008), it is relevant to map out what environmenteconomy win-win situations have been important for the development of the Biofuel Region. However, when doing so, it is important to pay attention to the underlying motivations for the renewable energy project in the Biofuel Region, since previous EPI studies show that renewable energy projects initiated on environmental grounds are more durable and long-term than renewable energy projects initiated for other reasons (such as economic growth or supply-security) (Söderberg, 2008).

In the third section, the framing of bioenergy as well as institutional and structural factors in the Biofuel Region are explored on basis of the analytical framework structured above, with the aim to understand the driving forces behind the Biofuel Region, and how the interaction between different governance levels in a multilevel governance structure impacts on sub-national bioenergy development in this particular case. The policy frames guiding the Biofuel Region are detected through outlining how policy goals; underlying problems; policy preferences (instruments and strategies); and promoted values and role of bioenergy have been articulated in the Biofuel Region between the years 2003-2010. This part of the analysis draws on both document studies and interviews and serves the purpose of detecting both the driving forces for sub-national bioenergy development over time as well as whether the subnational framing can be classified as EPI.

\section{Results: sub-national bioenergy development and framing of bioenergy}

The Biofuel Region is a "strategic network", uniting public actors, business and research, and was initiated in 2003 by a few municipalities and companies in the north of Sweden, mainly situated in the (forest-covered) counties of Västerbotten and Västernorrland. In 2013, The Biofuel Region involved 11 municipalities,16 business actors and received financial support from the Swedish Energy Agency, the Swedish Board of Agriculture, and from three (Norrbotten, Västerbotten, Västernorrland) county and regional administrations. The Biofuel Region works in three main focus areas. Societal transition spreads information to sub-national actors and citizens, for example through collaborations with teachers and municipal 
authorities. Industrial and regional development supports the development of research and production of renewable fuels in the region, e.g. through coordinating biogas producers in north Sweden with the aim of making biogas a large-scale biofuel in the region. Raw material contains research on energy crops; on intensifying the use of forest in a sustainable manner (within the research project Future Forest) and on retrieving more energy from the forest (within the research project Forest Power).

The following two subsections explore how the institutional and structural factors (in accordance with the analytical framework) behind the formation and direction of the Biofuel Region have evolved over time (2003-2006 and 2006-2010). Through this approach, institutional and structural explanations to the biofuel interest in the region can be detected. Thereafter, the framing of bioenergy over time is outlined in order to explore how relevant environmental aspects are on the sub-national level and if this can be classified as EPI. The findings in this section form the basis for cross-level comparison with the national and EU-level framing of and approach to bioenergy the is provided in the next section.

\section{Institutional and structural factors 2003-2006}

Christensen (2005, pp. 21-23) provides four main explanations for the launch of the Biofuel Region: 1) the long tradition of interest in energy issues in the region's energy and forest industries; 2) the environmental interest uniting the seven key persons in the process management group; 3 ) the process management group's good insights into the handling of institutional processes at the national and subnational level; and 4) the EU biofuel directive 2003/30/EC (EC, 2003), obliging Member States to ensure that biofuels and other renewable fuels accounted for at least 2 percent of transport fuels by 2005, and at least 5.75 percent by 2010 .

The Biofuel Region itself points out two main aspects as initiating factors: first, the increased production of both bioethanol- and flexifuel-cars, which had been initiated by BAFF (Bioalcohol Fuel Foundation) during the first years of the new millennium; second, the county board of Västernorrland's recognition of a strong biofuel cluster as a potential winner of Vinnväxt (see below) grants from the Swedish Governmental Agency for Innovation Systems (VINNOVA), which supports research and development with the aim to promote "growth and prosperity throughout Sweden" (BFR, 2007; VINNOVA, 2010). VINNOVA's Vinnväxt Programme started in 2001 and aims to "promote sustainable growth by developing internationally competitive research and innovation environments in specific growth fields" (VINNOVA, 2010a). The Västernorrland project, Biorefinery of the Future, based in Biofuel Region member cities Örnsköldsvik and Umeå, develops "biorefineries based on forest raw materials and energy crops" (VINNOVA 2010b) and received grants ( $\approx 400.000$ annually for ten years) in 2008. VINNOVA's motivation was that the project had a good potential to create sustainable growth (VINNOVA, 2010c).

The first steps towards forming the Biofuel Region were taken by a handful of people, attempting to gain national financial support for developing a biodiesel industry in the county of Västernorrland in 2002. However, the break-through for the Biofuel Region came in 2003, when the bioethanol champion and BAFFchairman Per Carstedt became process manager. As goals were set for the organisation and municipal politicians saw the opportunity for creating regional growth, the Biofuel Region grew quickly with focus on bioethanol production. All interviewees explain this ethanol focus with the involvement of the Bioalcohol Fuel Foundation (BAFF, a foundation aiming to develop production techniques and use of bioethanol within the transport sector) and $\mathrm{SEKAB}^{2}$ (a Swedish producer and

\footnotetext{
${ }^{2}$ SEKAB: Svensk etanolkemi AB.
} 
distributor of bioethanol and green chemicals, also developing 2nd generation biofuels; cellulose-based bioethanol) in the project. SEKAB is by far the largest actor on the Swedish ethanol market and also an important actor on the European ethanol market (SwedWatch, 2009), and the ethanol focus within BFR grew stronger as ethanol cars became more common and as the ethanol distribution system was improved, partly due to national Swedish regulations.

\section{Institutional and structural factors 2006-2010}

Per Carstedt saw business opportunities as BAFF was involved in building ethanol and flexifuel cars, while other members of the Biofuel Region, especially the municipalities with rich forest assets, saw risks for a conflict of interest between the wood industry and the ethanol industry regarding raw material. This potential conflict of interest, along with the global ethanol debate that questioned the sustainability of (mainly cereal-based) bioethanol (e.g. Giampietro and Mayumi, 2009), was behind the broadened focus within the Biofuel Region after 2007. "Biogas as a fuel has gained ground and taken ethanol's place since biogas is a better fuel. It is less controversial and has better environmental and climate features but is more difficult to commercialise: ethanol is easier" (Interview 8).

The controversy over ethanol which the interviewee refers to also has to do with another factor behind the broadened focus of the Biofuel Region, namely SEKAB's investments from 2005 and onwards in sugar cane- and durra-based ethanol production in Africa, mainly Tanzania and Mozambique, with the intention to build up large-scale (400,000 hectares of energy crop plantations) ethanol production in Africa. However, the project received strong criticism early on in a report claiming that SEKAB's large-scale plantation plans threatened valuable nature areas and risked crowding out the local farming population (ABN, 2007). The project also received criticism regarding the appropriateness of using municipal money (SEKAB is partly owned by two municipal energy companies, Övik energi and Skellefteå kraft; and one municipality, Umeå kommun) for investments abroad (SEKABinvestments had also been made in Poland and Hungary). These discussions forced SEKAB to put their investment plans for expansion abroad on hold and seek other investors in 2008 (SwedWatch, 2009).

The debate on the sustainability of ethanol as a fuel, and SEKABs controversial plans of starting up biofuels production in Africa, however generated a lot of subnational discussions, and, in combination with the economic recession, the Biofuel Region saw turbulent times with members leaving. As expressed by one interviewee: "The Biofuel Region was drawn into the SEKAB-story" (Interview 2). Therefore, it became important for the Biofuel Region to broaden its scope and focus on becoming an alternative fuels region rather than "being just a marketing organisation for SEKAB" (Interview 1) to regain the trust of its members. However, the member loss in the wake of the ethanol- and SEKAB discussions and the economic recession was notable. The Biofuel Region had 17 municipalities as members in 2008; in autumn 2010 the Biofuel Region had 11 municipalities as members. It seems that the driving forces were different between those who left the Biofuel Region and those who endured through the crisis: "When the Biofuel Region started, some municipalities had unrealistic expectations of increased job growth ... Those who stayed entered with more realistic expectations. These municipalities also contain individuals who are committed" (Interview 3 ).

\section{The Framing of Bioenergy}

\section{Underlying Problems}

In a report summarising the first three years of BFRs work, the background to the project is described in global terms. The report refers to the increasing attention to the climate issue with the Stern report (Stern, 2007) and the IPCC report (IPCC, 
2007) and to the 'Peak Oil' theory ${ }^{3}$ and the increasing oil prices as factors important for the BFR work, and as justification for the strive to reduce the dependence of fossil fuels within the Biofuel Region (BFR, 2007a). Similar values are expressed in interviews: "The oil is gone within the heat and industrial sector, apart from coal and coke use [within the steel industry]. But the transport sector remains, and the Biofuel Region can help there, to capture the many opportunities available" (Interview 6).

Many of the interviewees point out that the transport sector within the northernmost Swedish counties are highly dependent on fossil fuels, and that the underlying problem that BFR can help solving is the transition from fossil fuels to renewable fuels within the transport sector, which globally is driven by the climate change debate (Interviews 3, 6, 7, 10).

In the initial phase, when the Biofuel Region was formed, focus was therefore on the north-Swedish oil-dependence rather than on the climate change aspect. Please note, however, that the climate change focus within BFR has grown over time as the issue has become more generally known by citizens, politicians and sub-national companies. The increasing global climate change debate and the ensuing request for renewable energy has made sub-national actors more open to these issues and to the business opportunities provided by renewable energy production (Interview 2).

On the regional level, though, the main focus is on growth and municipalities have hesitated to join the Biofuel Region due to the costs involved. Therefore, interviewees hold that the most important problem that needs to be addressed by the Biofuel Region is the lack of knowledge regarding biofuels amongst local, regional and national politicians, citizens and companies, and to provide an arena for cooperation between municipalities, companies and researchers. Within tight budgets, municipal politicians need to prioritise between environmental development issues and the core areas (education, social care and health care), and there seems to be different driving forces for joining the Biofuel Region project and for withdrawing from the project. For joining the project, environmental arguments are important mainly for convincing municipal politicians that investment in biofuels provides opportunities for job creation and regional growth. However, when leaving the Biofuel Region, economic reasons are the most important ones; when the process is too slow in creating new jobs, municipalities tend to prioritise other areas. After 2007, however, the municipal knowledge of the global climate change debate has increased and, with that, the acceptance for the necessity of longer-term horizons regarding the regional biofuel development has increased amongst municipal actors (Interviews 2, 3, 4, 5, 6, 8, 9, 10).

Thus, initially, reduction of the oil-dependency of the region with a view to the 'Peak Oil'-theory was the underlying problem for the Biofuel Region as an organisation. After 2007, however, the transition to renewable energy within transport for climate change mitigation is the underlying problem driving leading the Biofuel Region actors, and this is also emphasised within official Biofuel Region documents (BFR, 2007a, 2008, 2009, 2010). An example of this is the adoption of a new set of core values in 2008, which emphasises the development of the Biofuel Region towards focusing on environmental sustainability, which states that: "Our driving force is global climate change and the necessity of quickly developing and using sustainable solutions for the oil-dependent transport sector... we have a holistic view and strive for sustainable development in our work" (BFR, 2008, p. 5). However, for municipal politicians, the increasing attention to climate change and renewable energy are merely viewed as evidence for a long-term business opportunity; when becoming aware of the global debate, municipal politicians see

\footnotetext{
${ }^{3}$ Peak Oil theory predicts that the world supply of oil will peak and be unable to meet the increasing global demand around the early 2000s (see e.g. Robelius, 2007).
} 
the opportunities for solving unemployment problems through creating "green growth" in their region.

\section{Policy Goals}

The Biofuel Region's original aim was to: 1 ) be a role model for the transition from fossil fuels to celloluse-based biofuels; 2) create industrial and regional development; 3) be knowledge leading also in 2020; and 4) to become selfsufficient regarding biofuels in 2030 (BFR, 2007a, p. 2). As these goals suggest, growth within the region and self-sufficiency were in focus when the project started, even though the focus on bioenergy was driven by global peak oil-, climate change-, and renewable energy debates: "Climate change is the foundation of our work, but also growth; the interest in the regional industrial development has increased in the last years. The Biofuel Region does not accomplish the industrial development; but the Biofuel Region can improve the conditions for it" (Interview 10).

When asked to describe the purpose of the Biofuel Region, in their own words, most interviewees emphasise that the goal is to become a world-leading region for the transition from fossil fuels to biofuels through increasing the knowledge about, and interest in, biofuel use and production (Interviews 1, 3, 4, 5, 6, 8, 9). Many interviewees point out that an important aim for the Biofuel Region is to make sure that the regional companies discover the existing possibilities for bioenergy production within the Biofuel Region area and uses this opportunity for regional growth (Interviews 3,6, 9, 10). These views are confirmed within official Biofuel Region documents, where three policy goals, slightly different from the original ones, are emphasised in 2009: 1) to become leading in knowledge on societal transition to renewable energy; 2) to create industrial and regional development; and 3 ) to increase the supply of renewable raw material (BFR 2009). In 2013, the BFR official webpage stated that the overarching goal of the organisation is to replace products and services, which are bad for the environment and health with sustainable products and services (www.biofuelregion.se).

Thus, the focus-change is visible also in the policy goals of the Biofuel Region. Initially, focus lay on producing specifically cellulose-based biofuels and there was an emphasis on achieving self-sufficiency for the region. This supports the suspicion that focus in the initial phase lay on reducing oil-dependency within the region. After 2007, however, the focus has changed to broad transition towards renewable energy and an increase in renewable raw material supply are emphasised within the organisation. This refocus seems to indicate a slight reframing of bioenergy within the Biofuel Region, from bioenergy as a way to reduce regional oil-dependency to bioenergy as a renewable energy source.

\section{Policy Preferences}

The interviewed Biofuel Region actors emphasise the importance of clear politically determined renewable energy goals for the development within the Biofuel Region, but also point out the need for initial economic support from higher policy levels; both in terms of investments in new technology and in terms of research and development of new technology. Many of the interviewees however emphasise that central government funding is only needed initially - until the market feels secure enough for other investors. Other types of general policy instruments such as electricity certificates and CO2-tax are also emphasised as important for the development in the Biofuel Region, as well as the Swedish law of 2006, which forces gas stations of a certain size to provide alternative fuels (Interviews 1, 2, 3, $4,5,6,7)$. The importance of economic support is also put forward within official Biofuel Region documents: "The money provided by municipalities, companies and the Swedish Transport Administration during 2007 continue to be a crucial success factor for the Biofuel Region. Without these the process would never have come as far as it now has" (BFR 2007a: 1). Thus, Biofuel Region actors put renewable 
policy goals and political funding of investments in renewable energy forward as important policy instruments for sub-national bioenergy development.

\section{Promoted Values and Role of Bioenergy}

"We are highly fossil-dependent in this region, and are in the hands of the fossil industry. The price is increasing and this will affect citizens and companies. [Biofuel Region members] are aware of bioenergy as an issue with potential" (Interview 5). When talking to Biofuel Region members, the role of bioenergy is double; it is both an energy source which can reduce regional fossil-fuel import dependence through domestic production, and a renewable energy source with regional growthgenerating potential (Interview 2, 4, 5, 7, 8, 9, 10). Many interviewees point out that the climate change issue has become more important for the Biofuel Region debate since 2007; in the initial phase the main argument was 'peak oil': "The climate issue was not important - we were running out of oil, we needed to adjust and we have forest" (Interview 2).

Similarly, the international ethanol debate has changed the focus within the Biofuel Region since 2007. Initially, ethanol and biodiesel was the main fuels within the Biofuel Region. Today, there is a broader focus on different alternative fuels, where also the environmental consequences from different renewable energy sources are weighed in (Interview 7): "We realised that there are many solutions; big challenges demand different fuels, we cannot put all our eggs in one basket. This was part of the global debate, but the Biofuel Region realised this early on" (Interview 5). The environmental perspective is forwarded in many of the interviews, which also emphasise that it is important to make use of the possibilities in the region for creating green regional growth (Interviews 2, 4, 5, 6, 7, 8, 9, 10).

A summary of the developments in the Biofuel Region over time is provided in Table 1. A discussion of how the framing of bioenergy and the institutional and structural factors outlined in this section correspond to the view on bioenergy on the EU and Swedish levels is provided in the fourth section. Furthermore, how the development of the Biofuel Region can be understood in a multi-level context is discussed based on the findings in this section and based on the results from interviews with key actors in the Biofuel Region.

\section{Discussion}

\section{EU-Sweden-biofuel region: a cross-level comparison of EPI in bioenergy}

Within EU energy, agricultural and transport policy, bioenergy and biofuels have been forwarded mainly on the basis of energy security, climate change and rural development arguments during 2003-2013 and the EPI in bioenergy within the EU can be classified as 'weak' given that 'the integration seems to be a matter of finding win-win solutions through combining environmental, security and economic goals" (Söderberg and Eckerberg, 2013 p. 117). In Swedish energy and agricultural policy, the arguments for promoting bioenergy and biofuels during the last decade have focused mainly on sustainability and entrepreneurial opportunities, with the addendum of supply security from 2007 and onwards. EPI in bioenergy in Sweden can be classified as 'weak' given that focus lies on combining different goals rather than on prioritising environmental aspects (Söderberg, 2011a, 2011b).

Within the Biofuel Region, bioenergy was initially framed as an opportunity for the region to become independent from the oil-industry through domestic production of biofuel using the region's rich assets of forest as raw material: 'bioenergy-for-selfsufficiency'. With the global climate change debate, biofuels have been reframed within the Biofuel Region. After 2007, the transition to a sustainable transport 
sector combined with the possibilities for green growth in the region is forwarded. As mentioned above, also the policy goals show signs of biofuel reframing, from framing specific biofuels as an opportunity for making the region self-sufficient of fuel to, after 2007, framing biofuels broadly as a renewable energy source that has an important role in societal transition. After 2007, the underlying problems for the Biofuel Region are an oil-dependent transport sector and climate change; the policy goal is to achieve societal transition to renewable energy; the policy preferences are supra-national and national renewable policy goals and political investments in renewable energy; and the promoted values and the role of bioenergy is mainly viewing biofuels as a potential green regional growth-sector: 'bioenergy-for-green-transition-and-growth'.

Thus, an environmental perspective is present within the Biofuel Region official documents, expressed amongst key actors and is also present within policy strategies. This indicates that the integration of an environmental perspective is not just a matter of rhetorical or instrumental environmental learning: rather, there is EPI also in bioenergy policy on the sub-national level in the Biofuel Region case. However, the environment is not the single driving force for the development within the Biofuel Region, as will be further addressed below. Furthermore, the relevance of environmental arguments seem to differ between different actors within the Biofuel Region, which may explain why the environment, though given a significantly more prominent place after 2007, is still tightly tied to growth opportunities within the Biofuel Region. Thus, similar to the EPI on the EU and Swedish level, also the EPI within the Biofuel Region can be classified as weak. A cross-level overview of the view on bioenergy is provided in Table 1.

Table 1: Framing of bioenergy: a cross-level overview

\begin{tabular}{|c|c|}
\hline EU 2003-2013 & $\begin{array}{c}\text { Bioenergy promotion based on energy security, climate change and rural } \\
\text { development arguments. Weak EPI. }\end{array}$ \\
\hline Sweden 2000-2013 & $\begin{array}{l}\text { Bioenergy promotion based on sustainability and entrepreneurship } \\
\text { arguments. From } 2007 \text { also energy security important. Weak EPI. } \\
\text { Underlying problems: Oil dependent transport sector, Unemployment }\end{array}$ \\
\hline $\begin{array}{l}\text { Biofuel Region } 2003-2006 \\
\text { 'bioenergy-for-self- } \\
\text { sufficiency' }\end{array}$ & $\begin{array}{c}\text { Policy goals: Self-sufficiency for BFR and regional growth } \\
\text { Policy preferences: Supra-national and national investments in specific } \\
\text { biofuels }\end{array}$ \\
\hline $\begin{array}{l}\text { Biofuel Region } 2007-2010 \\
\text { 'bioenergy-for-green- } \\
\text { transition-and-growth' }\end{array}$ & $\begin{array}{c}\text { Role of bioenergy: Potential regional growth sector } \\
\text { Underlying problems: Oil dependent transport sector, Climate change } \\
\text { Policy goals: To achieve societal transition to renewable energy } \\
\text { Policy preferences: Supra-national and national renewable energy policy } \\
\text { goals and investments } \\
\text { Role of bioenergy: Potential green regional growth sector }\end{array}$ \\
\hline
\end{tabular}

\section{EU-Sweden-Biofuel Region: the role and nature of multi-level interplay}

Biofuel Region actors hold that Swedish policy affects the Biofuel Region indirectly, mainly through national energy policy and research policy: "economic factors play a much larger role than one wants to admit" (Interview 3). Many of the interviewees mention policy measures such as the 'green car premium' (a national economic premium for buyers of new cars fulfilling certain environmental criteria) and the 'pump law' of 2006 (which forces gas stations of a certain size to provide alternative fuels), as well as the CO2-tax on petrol and economic support in the form central government funding from which organisations can apply for project support as important for the development within the Biofuel Region (Interview 3, 4, $5,9,10)$. Furthermore, national financial contributions to research projects are pointed out as crucial: "the Biofuel Region is dependent on the opportunity to apply for money via scientific research" (Interview 1).

Many of the interviewees also point out the importance of national economic support in the initial state of building up renewable energy production and new technologies: "Biofuels is a growing business. Market forces do not work in the 
initial phase and therefore economic measures are crucial" (Interview 8). Regarding the role of the environmental perspective within the Biofuel Region, one interviewee argues that: "today environment, sustainability and self-sufficiency is on the agenda for all political parties", which means that environmental issues are no longer controversial (Interview 4). At the same time, it is also emphasized that both national and EU-regulations defines what is and is not environmentally friendly; what is regarded a "green car" and a "sustainable fuel", for example, is to a large extent guided by national and EU-definitions (Interview 4).

As regards EU-policy, apart from defining what is and is not sustainable, it also affects the Biofuel Region mainly in two other ways. First of all, climate policy and environmental issues are high on the EU-agenda and EU-level policy goals provide sub-national bioenergy actors with long-term conditions for development and with good arguments when discussing with potential contributors to their project. Especially EU-goals for renewable energy, such as the 20 percent renewable energy in 2020-goal (COM 2006/848) and the Biofuels Directive are pointed out as important for the development within the Biofuel Region (Interview 1, 3, 4, 5, 6, 8, $9,10)$.

Second, EU-supported projects have been important for Biofuel Region development recently, however there is one big catch involved in this area: lack of competence regarding EU-level project applications: "the companies have difficulties in finding the time and competence...but the EU-money is important we need to improve our skills in bringing these funds in" (Interview 9). At the same time, the EU-membership opens up the opportunity to form projects together with other European regions and the Biofuel Region has received financial support for projects from the EU-level, such as within the EU-financed project BEST (Bioethanol for sustainable transport) (Interview 2). Furthermore, EU-projects to a large extent set the agenda for sub-national bioenergy actors: "EU-supports are very steering regarding what we choose to get on. If you can get $40 \%$ support from the EU plus the county board you tend to go in that direction" (Interview 4).

When it comes to cross-level contacts, Biofuel Region actors are invited to EUseminars and to national seminars, and the organisation is also a body considering proposed legislation regarding energy policy. However, most interviewees claim that the Biofuel Region could improve in the area of bottom-up contacts, even though there are informal and formal contacts with national agencies such as the Swedish Energy Agency and the Swedish Board of Agriculture. Some of the interviewees also point out that cross-level interaction through personal contacts were more important in the initial phase of the Biofuel Region: "Per Carstedt was good at using political channels in Örnsköldsvik, via Elvy Söderström [Social Democrat with a leading municipal position] to Göran Persson [Social Democratic prime minister 1996-2006]" (Interview 9). Per Carstedt has been claimed to have had good relations both with leading Social Democrats and with Ministers from the four-party coalition governing Sweden 2006-2010 (e.g. Miljöaktuellt, 2008). However, the main cross-level interaction, according to Biofuel Region actors, occurs through (top-down) political measures, energy policy regulations and through EU and Swedish policy setting the agenda for long-term policy development and project applications on the sub-national level.

\section{Conclusions and policy implications}

What drives sub-national bioenergy development, and what are the sub-national implications, in policy and practice, of higher-level EPI in the area of bioenergy policy? In the previous section, we saw that EPI on the EU, Swedish and the subnational (the Biofuel Region) levels can be classified as 'weak' as the environmental aspects are integrated but tightly tied to (and not prioritised over) other goals such as energy security and economic growth. In the Biofuel Region case, the main imprints of EU and Swedish EPI in bioenergy policy have been 
made through environmental agenda setting (i.e. steering what is sustainable through regulations and goals such as the EU Biofuels Directive and the Swedish 'green car premium' and 'pump law') and provision of economic preconditions for the development of local biofuels (e.g. project/research funding).

But there are also other important aspects, which provide explanations for subnational bioenergy development in this particular case. Job creation and local growth have been the main driving forces for joining the Biofuel Region for the smaller municipalities. This may also explain the slightly less environmental framing of biofuels in the initial phase of the Biofuel Region's work: environmental arguments were not efficient in gathering municipal support in 2003. As the environmental perspective has grown more important within EU- and Swedish policy in general and within bioenergy policy in particular, so has the environmental perspective also gained a more prominent place within the Biofuel Region.

The reframing of biofuels within the Biofuel Region (from 'bioenergy-for-selfsufficiency' in 2003-2006 to 'bioenergy-for-green-transition-and-growth' in 20072010) can thus be viewed as a way of building bridges between the different actors in the region and gather broad-based support for the biofuel development. In this regard, EPI progress in the Biofuel Region is well in line with Nilsson and Eckerberg's (2007, p. 158), claim that EPI success can be related to the development of win-win strategies. As shown by the Biofuel Region case, win-win strategies are highly important also for sub-national EPI.

When it comes to formal cross-level interactions, these are mainly top-down structured: EU and Swedish policy strategies and funding set the agenda for subnational bioenergy actors. Given the importance of financial support in the initial phase of new technology development, this study points out the relevance for supra-national and national politicians (if they want to promote sub-national bioenergy development) to make sure that their environmental rhetoric is followed up by environmentally motivated policy instruments encompassing financial resources which sub-national actors can apply for.

However, despite the importance of securing economic funding, one obstacle for sub-national bioenergy development within the Biofuel Region has been the lack of competence regarding applications for EU-funding. Here, sub-national actors need to improve their skills (or EU- and national politicians need to simplify the application procedure) if such EPI instruments are to have full-scale impact. This is especially important on the sub-national level, where different objectives are weighed against each other within tight budgets (Baker and Eckerberg, 2008), and therefore external economic support is crucial for development in areas such as renewable energy.

Thus, the development of the Biofuel Region can partly be explained by higherlevel EPI: EU and Swedish EPI in bioenergy policy has set the sub-national level policy agenda and provided financial resources for sub-national actors, who have reframed their objectives in line with the changing global debate. Although some bottom-up interaction occurs, and played a significant role through personal contacts in the initial phase, cross-level interactions in the Biofuel Region mainly take place through top-down mechanisms such as policy formulation, central government funding programmes and regulations. However, policies and economic instruments have to be implemented in practice on the sub-national level, and here the existence of 'policy entrepreneurs' is equally important to understand the development of the Biofuel Region.

Previous studies of EPI on the European and national level show that policy entrepreneurs are important for maintaining the environmental attention in a policy area (Nilsson and Eckerberg, 2007), and that renewable energy projects initiated on environmental grounds are more durable than renewable energy projects initiated for other reasons (e.g. to secure economic growth or supply-security) (Söderberg, 2008). According to the interviewees, those municipalities where 
genuinely environmentally interested persons held leading positions also entered the Biofuel Region with more realistic expectations and endured longer within the project. Those who mainly entered with the expectation of having biofuel factories in every municipality within a few years' time soon became disappointed. Thus, the Biofuel Region case shows that the presence of policy entrepreneurs and environmental motives for action that are central for EPI on the national and EUlevel also are important factors for EPI in sub-national settings.

Furthermore, external factors have been important for the initiation of the Biofuel Region project (policy windows in the form of Vinnväxt grants and the EU Biofuels Directive provided opportunities for the region), for the municipal level reframing and for the refocus of the Biofuel Region towards forming a broader renewable energy cluster rather than promoting a certain type of biofuel. In the Biofuel Region case, the initial direction (on ethanol - within the frame 'bioenergy-for-selfsufficiency') was set by the regional forest assets and by the companies involved, and this direction did not change (towards promoting different types of renewable energy within the frame 'bioenergy-for-green-transition-and-growth') until the global, EU and national debates on climate change and biofuels made it necessary to do so.

In sum, the Biofuel Region case shows that top-down policy instruments such as regulations and economic support drive the direction of sub-national renewable energy development (i.e. the types of energy sources that are developed and on what - environmental or non-environmental - grounds). Thus, the diminishing role of the state, which is often pointed out in MLG-studies, is only partly confirmed in this study. Although the EU sets the agenda and provides economic support to local projects, traditional governance from the national level still has an important steering role in the field of energy policy. EU and national policies set the agenda and preconditions for local renewable energy development and influence the degree of EPI also on the sub-national level.

However, the contacts between levels are mainly top-down oriented. Nevertheless, the Biofuel Region case also provides further understanding of why sub-national renewable energy development takes place in one location but not in others. Sweden, for example, is covered with forest but there is only one Biofuel Region. In order to initiate and maintain durable and sustainable renewable energy projects on the sub-national level, policy entrepreneurs capable of pointing towards local win-win-solutions, with extensive personal networks (to assure higher-level support for their particular local renewable energy project) and which are capable of applying for EU and national funding are crucial. Thus, although top-down steering provides the setting for sub-national renewable energy development and thus is a highly important mechanism for ensuring cross-level EPI, bottom-up contacts and local multi-actor networks also have important roles to play for local projects to be successful and sustainable.

\section{References}

ABN (2007) Agrofuels in Africa: the impact on land, food and forests. Case studies from Benin, Tanzania, Uganda and Zambia. Kenya: African Biodiversity Network. (Available at URL: http://africanbiodiversity.org/abn old/resources.html)

Bache, lan and Matthew Flinders (eds) (2004) Multi-level Governance. Oxford: Oxford Universtiy Press.

Baker, Susan and Katerina Eckerberg (2008) 'Conclusion: combining old and new governance in pursuit of sustainable development', in Susan Baker and Katerina Eckerberg (eds) In pursuit of sustainable development: New governance practices at the sub-national level in Europe. Oxon: Routledge, pp. 208-228.

Bergström, Göran and Kristina Boreus (2005) Textens mening och makt: metodbok i samhällsvetenskaplig textanalys. Lund: Studentlitteratur. 
BFR (2007) Verksamhetsberättelse av BioFuel Regions etapp I 2003-2006. Umeå: Biofuel Region.

BFR (2007a) Verksamhetsberättelse 2007. BioFuel Region AB and BioFuel Region Ideell Förening. Umeå: Biofuel Region.

BFR (2008) Verksamhetsberättelse 2008. BioFuel Region AB and BioFuel Region Ideell Förening. Umeå: Biofuel Region.

BFR (2009) Verksamhetsberättelse 2009. BioFuel Region AB and BioFuel Region Ideell Förening. Umeå: Biofuel Region.

BFR (2010) Verksamhetsberättelse 2010. BioFuel Region AB and BioFuel Region Ideell Förening. Umeå: Biofuel Region.

Christensen, Lars (2005) Formation for Collective Action: The development of Biofuel Region. Visanu 2005:10. Stockholm: Nutek Förlag.

Dryzek, John S. (2000) Deliberative democracy and beyond: liberals, critics, contestations. Oxford: Oxford University Press.

EC (2003) 'Proposal for a council regulation on establishing common rules for direct support schemes under the common agricultural policy and...', COM (2003) 23 final of 21/01/03. Commission of the European Communities: Brussels

EC (2005) 'Biomass action plan', COM (2005) 628 final of 7/12/05. Communication. Commission of the European Communities: Brussels

Eckerberg, Katarina and Björn Forsberg (1998) 'Implementing Agenda 21 in Local Government: the Swedish experience', Local Environment, 3 (2): 333-347.

EEA (2006) 'How much bioenergy can Europe produce without harming the environment?' European Environment Agency report 07/2006. Luxembourg: Office for Official Publications of the European Communitites.

Esaiasson, Peter, Mikael Gilljam, Henrik Oscarsson and Lena Wängnerud (2005) Metodpraktikan: Konsten att studera samhälle, individ och marknad. Stockholm: Norstedts Juridik AB.

Folke, Carl, Johan Colding and Friket Berkes (2002) 'Building resilience for adaptive capacity in social-ecological systems', in Friket Berkes, Johan Colding and Carl Folke (eds) Navigating Social-Ecological Systems: Building Resilience for Complexity and Change. Cambride: Cambridge University Press, pp. 352-387.

Giampietro, Mario and Kozo Mayumi (2009) The Biofuel Delusion: the fallacy of large-scale agro-biofuel production. London: Earthscan.

Gunderson, Lance and C.S. Holling (eds) (2002) Panarchy: Understanding Transformations in Human and Natural Systems. Washington, DC: Island Press.

Hall, Peter A. (1993) 'Policy paradigms, social learning, and the state', Comparative Politics 25 (2): 275-296.

Hooghe, Liesbet and Gary Marks (2003) 'Unraveling the central state, but how? Types of multi-level governance', American Political Science Review 97(2): 233243.

IPCC (2007) Fourth Assessment Report: Climate Change 2007. Geneva: Intergovernmental Panel on Climate Change.

Jacob, Klaus and Axel Volkery (2004) 'Institutions and Instruments for Government Self-Regulation: Environmental Policy Integration in a Cross-Country Perspective', Journal of Comparative Policy Analysis: Research and Practice 6(3): 291-309.

Jordan, Andrew (2002) 'Efficient hardware and light green software: Environmental policy integration in the UK', in Andrea Lenschow (ed) Environmental policy integration: Greening sectoral policies in Europe. London: Earthscan, pp. 35-56. 
Jordan, Andrew and Andrea Lenschow (2008) Innovation in Environmental Policy?: Integrating the Environment for Sustainability. Cheltenham: Edward Elgar.

Kingdon, John (1995) Agendas, Alternatives and Public Policies. Second Edition. New York: Harper Collins.

Lafferty, William M. (2004) 'From environmental protection to sustainable development: the challenge of decoupling through sectoral integration', in William M. Lafferty (ed) Governance for Sustainable Development. Cheltenham: Edward Elgar, pp. 191-220.

Lasswell, Harold D. (1950) Politics: Who Gets What, When, How. New York: Peter Smith.

Lenschow, Andrea (1999) 'The greening of the EU: the common agricultural policy and the structural funds', Environment and Planning C-Government and Policy 17 (1): 91-108.

Lenschow, Andrea (ed) (2002) Environmental Policy Integration: Greening Sectoral Policies in Europe. Earthscan, London.

Lenschow, Andrea and Anthony R. Zito(1998) 'Blurring or shifting of policy frames? Institutionalization of the economic-environmental policy linkage in the European Community', Governance 11 (4): 415-442.

Miljäaktuellt (2008) Mr Biofuel - Mauds okända rådgivare. URL(consulted at 200802-07): http://miljoaktuellt.idg.se/2.1845/1.144053

Nilsson, Mans (2005) 'Learning, Frames and Environmental Policy Integration: the case of Swedish energy policy', Environment and Planning C: Government and Policy 23 (2): 207-226.

Nilsson, Mans and Katarina Eckerberg (eds) (2007) Environmental Policy Integration in Practice. London: Earthscan.

Nilsson, Mans, Katarina Eckerberg and G. Finnveden (2007) 'Discussion: What Enabled EPI in Practice?', in Mans Nilsson and Katarina Eckerberg (eds) Environmental Policy Integration in Practice. London: Earthscan, pp.137-162.

Nilsson, Mans and Åsa Persson (2003) 'Framework for Analysing Environmental Policy Integration', Journal of Environmental Policy \& Planning 5 (4): 333-359.

Oberthür, Sebastian and Thomas Gehring (eds) (2006) Institutional Interaction in Global Environmental Governance. Synergy and Conflict among International and EU Policies. Cambridge: MIT Press.

Persson, Åsa. (2007) 'Different Perspectives on EPI', in Mans Nilsson and Katarina Eckerberg (eds) Environmental Policy Integration in Practice. London: Earthscan, pp. 25-47.

Radaelli, Claudio M. (2003) 'Europeanization of Public Policy', in Kevin Featherstone and Claudio M. Radaelli (eds) The Politics of Europeanization. Oxford: Oxford University Press, pp. 27-56.

Rein, Martin and Donald Schön (1993) 'Reframing policy discourse', in Frank Fischer and John Forester (eds) The argumentative Turn in Policy Analysis and Planning. Durham, NC: Duke University Press, pp. 145-166.

Rein, Martin and Donald Schön (1994) Frame Reflection. New York: BasicBooks.

Rhodes, Rod (2000) 'Governance and public administration', in Jon Pierre (ed) Debating Governance. Oxford: Oxford University Press, pp 54-90.

Robelius, Fredrik (2007) Giant Oil Fields - The Highway to Oil: Giant Oil Fields and their Importance for Future Oil Production. Doctoral Dissertation. Uppsala: Uppsala Dissertations from the Faculty of Science and Technology. 
Sabatier, Paul A. and Hank C. Jenkins-Smith (1999) 'The Advocacy Coalition Framework: An Assessment', in Paul A. Sabatier (ed) Theories of the Policy Process. Oxford: Westview, pp. 117-166.

Stagle, Sigrid (2007) 'Theoretical foundations of learning processes for sustainable development', International Journal of Sustainable Development and world ecology 14 (1): 52-62.

Stern Nicholas (2007) The economics of climate change: the Stern review. Cambridge University Press: Cambridge.

Swartling, Åsa G., Mans Nilsson, Rebecka Engström and Lovisa Hagberg (2007) 'Theory and Methodology for EPI Analysis', in Mans Nilsson and Katarina Eckerberg (eds) Environmental Policy Integration in Practice. London: Earthscan, pp. 25-47.

SwedWatch (2009) 'En brännande fråga. Hur hållbar är den etanol som importeras till Sverige?', SwedWatch rapport nr 25. Stockholm: SwedWatch.

Söderberg, Charlotta. (2008) 'Much Ado about Nothing?' Energy Forest Cultivation in Sweden: How Intersectoral Policy Coordination Affects Outcomes from EPI in Multisectoral Issues', Journal of Environmental Policy \& Planning 10(4): 381-403.

Söderberg, C. (2011a) 'Institutional conditions for multi-sector environmental policy integration in bioenergy', Environmental Politics (20) 4: 528-546.

Söderberg, Charlotta (2011b) Environmental policy integration in bioenergy: policy learning across sectors and levels? Doctoral thesis. Department of Political Science Research Report. Umeå: Umeå University.

Söderberg, Charlotta and Katarina Eckerberg (2013) 'Rising policy conflicts over bioenergy and forestry', Forest Policy and Economics 33: 112-117.

Urwin, Kate and Andrew Jordan (2008) 'Does public policy support or undermine climate change adaptation? Exploring policy interplay across different scales of governance', Global Environmental Change 18(1): 180-191.

Vinnova (2010) About VINNOVA. URL: http://www.vinnova.se/sv/In-English/AboutVINNOVA/ (2010-02-16)

Vinnova (2010a) VINNVÄXT: Regional Growth through Dynamic Innovation Systems. URL(consulted 2010-02-16): http://www.vinnova.se/lnEnglish/Activities/Strong-research-and-innovation-environments/VINNVAXT/

Vinnova (2010b) Winners. URL(consulted 2010-0216):http://www.vinnova.se/sv/In-English/Activities/Strong-research-and-innovationenvironments/VINNVAXT/Winners-2003-2004/.

Vinnova (2010c) Framtidens Bioraffinaderi. URL(consulted 2010-02-16): http://www.vinnova.se/sv/Verksamhet/Starka-forsknings--ochinnovationsmiljoer/VINNVAXT/Vinnare/2008/Framtidens-Bioraffinaderi/ .

WCED (1987) Our Common Future. United Nations World Commission on Environment and Development. Oxford: Oxford University Press. 